\title{
PENURUNAN KECEMASAN IBU HAMIL RISIKO TINGGI DALAM MENGHADAPI PERSALINAN MELALUI PAKET "HARMONI"
}

\author{
M.M. Setyaningsih ${ }^{1,2^{*}}$, Setyowati $^{3}$, Kuntarti $^{3}$ \\ 1. Akademi Keperawatan Panti Waluya Malang, Jawa Timur \\ 2. Program Studi Magister Fakultas Ilmu Keperawatan Universitas Indonesia, 16424 Depok \\ 3. Fakultas Ilmu Keperawatan Universitas Indonesia, 16424 Depok \\ *E-mail: maria_setyaningsih@yahoo.com
}

\begin{abstract}
Abstrak
Kondisi risiko tinggi pada kehamilan akan memengaruhi kondisi psikososial pada ibu, pasangan dan keluarganya. Masalah psikososial ini memerlukan intervensi khusus agar tidak memperburuk kondisi fisik ibu hamil yang dapat berpengaruh pada persalinannya. Tujuan penelitian ini untuk mengetahui pengaruh pemberian paket "Harmoni" pada ibu hamil risiko tinggi terhadap kecemasan ibu menghadapi persalinan. Intervensi ini meliputi pendidikan kesehatan tentang kehamilan risiko tinggi, berbagai tehnik relaksasi, bentuk dukungan kepada ibu dan cara meningkatkan kepercayaan diri. Pendidikan kesehatan ini diberikan dengan metode yang bervariasi. Penelitian kuasi eksperimen ini menggunakan sampel masing-masing sejumlah 20 ibu hamil risiko tinggi pada kelompok kontrol dan intervensi yang diambil secara consecutive sampling. Kecemasan diukur dengan modifikasi Hamilton Rating Scale for Anxiety (HRSA). Hasil penelitian menunjukkan ada pengaruh signifikan pada kelompok intervensi $(p=0,03 ; \alpha=0,05)$ setelah mendapatkan perlakuan. Paket "Harmoni" ini dapat digunakan sebagai media dalam pendidikan kesehatan psikososial bagi ibu hamil risiko tinggi dalam menghadapi persalinannya.
\end{abstract}

Kata kunci: kecemasan menghadapi persalinan, kehamilan risiko tinggi, paket harmoni

\begin{abstract}
Providing "Harmony" Package Decrease Childbirth Anxiety of High Risk Pregnant Women. High risk on pregnancy influences psychosocial condition of the mother, husband and their family. This psychosocial condition needs specific intervention to prevent worsening physical condition that affecting labor. The study purposed to examine the effect of intervention namely "Harmony" package for high-risk pregnant women toward their childbirth anxiety This intervention includes education about high risk pregnancy, various relaxation techniques, kind of mother support, and how to improve self confidence. This education was provided with several methods. A quasi-experimental design used sample of each 20 pregnant women in the control and intervention group were taken by consecutive sampling. Anxiety was measured with modified Hamilton Rating Scale for Anxiety (HRSA). The result showed that there is a significant effect of the "Harmony" package to the childbirth anxiety among the high risk pregnant women $(p=0,03 ; \alpha=0,05)$. "Harmony" Package is suggested to apply as psychosocial education for high-risk pregnant women to assist them in dealing with childbirth anxiety.
\end{abstract}

Keywords: childbirth anxiety, harmony package, high-risk pregnancy

\section{Pendahuluan}

Kehamilan seorang ibu dapat berada dalam kategori risiko tinggi. Ibu hamil dikategorikan sebagai kelompok risiko tinggi apabila kehamilannya tidak dikehendaki atau tidak diinginkan; mengalami komplikasi atau penyulit selama kehamilan, seperti perdarahan, lahir prematur, dan janin didiagnosa anomaly congenital; penyakit sebelumnya yang mengganggu kehamilan seperti jantung, asma, kelainan darah dan sebagainya, depresi, kekerasan dalam rumah tangga; dan ibu mempunyai riwayat kehamilan risiko tinggi sebelumnya atau kehilangan janin, seperti: kematian janin, keguguran, dan terminasi (Gilbert \& Harmon, 2010). Kondisi risiko tinggi ini tidak saja berkaitan dengan fisik tetapi juga berdampak pada aspek ibu yang lainnya. 
Kehamilan berisiko tinggi sangat memengaruhi kondisi psikologis, sosial dan emosional ibu dan pasangan serta keluarga. Ibu hamil mudah marah, takut, cemas, dan merasa gagal sebagai seorang wanita yang normal. Kondisi ini dapat menimbulkan gangguan keseimbangan dalam keluarga, akibatnya proses kehamilan ini dirasakan semakin sulit. Keadaan ini menimbulkan stres bagi ibu dan keluarga, mengakibatkan adanya perubahan dalam pola makan, pola tidur, peran sebagai ibu di rumah, pengasuhan anak yang lain, seksualitas, aktivitas dan rekreasi/ kunjungan sosial, sehingga hal ini dapat merusak aktivitas kerja atau perencanaan dari karir ibu. Ibu hamil risiko tinggi membutuhkan waktu untuk mempersiapkan diri dalam menerima kegagalan atau kehilangan kesempatan menjadi seorang ibu seperti ibuibu lain yang memiliki kehamilan normal, karena kehamilan risiko tinggi berisiko mengalami proses persalinan dini dan komplikasi (Bennington, 2012).

Penelitian Raja Lexshimi, Ho, Hamidah, Rohani, dan Syed Zulkifli (2007) tentang tingkat kecemasan dan depresi pada ibu hamil risiko tinggi di bangsal obstetri, didapatkan hasil bahwa $42.1 \%$ ibu hamil risiko tinggi mengalami kecemasan ringan dan $57.9 \%$ ibu hamil risiko tinggi mengalami kecemasan berat. Ibu hamil risiko tinggi yang dapat diklasifikasikan mengalami depresi ringan (44.7\%) dan depresi berat $(55.3 \%)$. Penyebab terjadinya kecemasan pada ibu hamil risiko tinggi sesuai dengan hasil penelitian Raja Lexshimi, et al. (2007) adalah kurangnya informasi yang didapatkan pasien dan keluarga tentang penyakit/ keadaan ibu, adanya faktor dalam keluarga dan keadaan sosial ekonomi. Oleh karena itu, dukungan psikososial perlu diberikan pada ibu hamil risiko tinggi (Dole, et al., 2003; Stankaitis, Brill, \& Walker, 2005; Sittner, Hudson, \& Defrain, 2007; Nakamura, Yoshigama, \& Atogami, 2011). Peran tenaga kesehatan untuk memberikan informasi tentang bentuk, manfaat, tujuan dari dukungan psikososial kepada pasangan sangat diperlukan. Hal ini penting agar ibu merasa bahwa dirinya mendapatkan dukungan penuh dari suami, dengan demikian, mereka dapat mempersiapkan diri menghadapi keadaan yang akan terjadi dalam keluarga (Foux, 2008).

Upaya menurunkan kecemasan pada ibu hamil risiko tinggi dapat diwujudkan dengan intervensi keperawatan berupa pendidikan kesehatan. Pendidikan kesehatan merupakan bagian dari promosi kesehatan, yang menurut World Health Organization (WHO), "Promosi kesehatan termasuk membentuk individu berpola hidup sehat, menciptakan lingkungan hidup yang sehat, membangun dan memperkuat aksi komunitas untuk berfokus kepada promosi kesehatan dan pencegahan penyakit dan masalah dalam kesehatan (WHO, 2013). Penelitian ini bertujuan mengindentifikasi pengaruh pemberian paket intervensi keperawatan psikososial yang diberi nama "Harmoni" terhadap kecemasan ibu menghadapi persalinan pada ibu dengan kehamilan risiko tinggi.

\section{Metode}

Desain penelitian yang digunakan adalah kuasi eksperimen dengan pendekatan pre dan posttes pada kelompok intervensi maupun kelompok kontrol. Sampel dalam penelitian ini adalah semua ibu hamil risiko tinggi yang periksa di beberapa Rumah Sakit di Kota Malang yang memiliki karakter yang sama. Sampel diambil secara consecutive sampling, sesuai kriteria inklusi, yaitu ibu hamil yang dikategorikan risiko tinggi menurut diagnosis medis, janin tidak mengalami kelainan, dan secara fiski dan psikis ibu dinyatakan sehat. Jumlah sampel yang penelitian ini adalah 20 orang kelompok intervensi dan 20 orang kelompok kontrol.

Perlakuan pada penelitian ini adalah pemberian paket "Harmoni". Paket ini berupa pendidikan kesehatan tentang kehamilan risiko tinggi, berbagai teknik relaksasi, bentuk dukungan dan cara meningkatkan kepercayaan diri. Paket pendidikan kesehatan ini diberikan dengan metode ceramah, diskusi, demonstrasi dan latihan. Sebagai pelengkap pendidikan kesehatan ini, responden juga diberikan buklet. Selama proses pendidikan kesehatan, perlakuan ini juga melibatkan suami responden. 
Alat pengumpul data berupa kuesioner karakteristik responden dan alat untuk mengukur stress yang menggunakan modifikasi Hamilton Rating Scale for Anxiety (HRSA). Hasil uji validitas instrumen ini berada pada rentang 0,39-0,79, sedangkan Cronbach's Alpha menunjukkan nilai 0,948. Hasil ini menunjukkan bahwa instrument ini valid dan reliabel.

Persetujuan etik diperoleh dari Komite Etik Penelitian Fakultas Ilmu Keperawatan Universitas Indonesia. Penelitian dilaksanakan setelah mendapatkan izin administrasi dari semua tempat penelitian. Analisis univariat untuk mendiskripsikan distribusi frekuensi masing-masing variabel bebas dan terikat, sedangkan analisis bivariat diawali dengan melakukan uji homogenitas menggunakan uji chi square untuk data kategorik dan uji levene's untuk data numerik. Analisis dilanjutkan dengan uji dependensi untuk mengetahui perbedaan kecemasan sebelum dan setelah intervensi dengan menggunakan uji Chi Square.

\section{Hasil}

Karakteristik responden meliputi usia, tingkat pendidikan,dan gravida. Rerata umur 25.74 (SD 6.97) pada kelompok kontrol, dan 31.95 (SD 5.02). Untuk karakteristik lainnya dapat dilihat pada Tabel 1. Pada uji homogenitas menunjukkan bahwa kedua kelompok setara.

Pada penelitian ini (lihat Tabel 2) menunjukkan bahwa bahwa pada periode sebelum diberikan perlakuan responden yang mengalami kecemasan ada $6(30 \%)$ pada kelompok kontrol dan $5(25 \%)$ pada kelompok intervensi. Saat pre-test tidak terdapat perbedaan yang signifikan kejadian kecemasn pada kelompok intervensi dan kontrol $(p=1,00 ; \alpha=0,05)$.

Tabel 3 menunjukkan ada perbedaan kejadian kecemasan sebelum dan sesudah diberikan paket "Harmoni" pada kelompok intervensi. Dari olah data diperoleh saat sebelum perlakuan (pre test) ada $75 \%$ responden yang tidak mengalami kecemasan dan setelah perlakuan (post test) didapatkan $100 \%$ responden tidak mengalami kecemasan. Hasil uji statistik Chi Square (Fisher Exact test) menyimpulkan ada pengaruh yang bermakna atas pemberian "Paket Harmoni" pada kelompok intervensi terhadap kecemasan para ibu hamil risiko tinggi dalam menghadapi persalinan $(\mathrm{p}=0,047 ; \alpha=0,05)$.

Penelitian ini menunjukkan (lihat Tabel 4) bahwa pada periode setelah diberikan paket "Harmoni" pada kelompok intervensi, diperoleh bahwa $100 \%$ responden pada kelompok intervensi tidak mengalami kecemasan. Hasil uji statistik Chi Square (Fisher Exact test) menyimpulkan bahwa terdapat pengaruh yang bermakna atas pemberian "Paket Harmoni" pada kelompok intervensi terhadap kecemasan para ibu hamil risiko tinggi dalam menghadapi persalinan, $(p=0,003 ; \alpha=0,05)$.

Hasil penelitian pada tabel 5 menunjukkan bahwa setelah diberikan paket "Harmoni", proporsi tidak cemas pada kelompok intervensi berbeda bermakna dengan kelompok kontrol $(\mathrm{p}=0,001$; $\alpha=0,05$ ), sedangkan pada kelompok lain tidak berbeda bermakna. Pada kelompok intervensi ini juga menunjukkan kecemasan yang semakin menurun pada saat perlakuan yang diberikan yaitu pada hari ketiga dan kelima kemudian setelah akhir perlakukan (gambar 1).

Tabel 1. Karakteristik Responden

\begin{tabular}{lcccc}
\hline & \multirow{2}{*}{ Variabel } & \multicolumn{2}{c}{ Kelompok Kontrol } & \multicolumn{2}{c}{ Kelompok Intervansi } \\
\cline { 2 - 5 } & F & \% & F & \% \\
\hline Pendidikan & 8 & 40 & 2 & 10 \\
Dasar & 8 & 40 & 10 & 50 \\
Menengah & 4 & 20 & 8 & 40 \\
Tinggi & & & & \\
Gravida & 15 & 75 & 4 & 20 \\
Primigravida & 5 & 25 & 16 & 80 \\
Multigravida & & & & \\
\hline
\end{tabular}


Tabel 2. Perbedaan Kecemasan Reponden Sebelum Perlakuan Pada Kelompok Kontrol Dan Kelompok Intervensi

\begin{tabular}{|c|c|c|c|c|c|c|c|}
\hline \multirow{3}{*}{ Kelompok } & \multicolumn{4}{|c|}{$\begin{array}{c}\text { Kecemasan } \\
\text { Sebelum Perlakuan }\end{array}$} & \multirow{2}{*}{\multicolumn{2}{|c|}{ Total }} & \multirow{3}{*}{$\mathbf{p}$} \\
\hline & \multicolumn{2}{|c|}{ Cemas } & \multicolumn{2}{|c|}{ Tidak Cemas } & & & \\
\hline & $\mathbf{N}$ & $\%$ & $\mathbf{n}$ & $\%$ & $\mathbf{n}$ & $\%$ & \\
\hline Kontrol & 6 & 30,0 & 14 & 70,0 & 20 & 100,0 & 1,00 \\
\hline Intervensi & 5 & 25,0 & 15 & 75,0 & 20 & 100,0 & \\
\hline
\end{tabular}

Tabel 3. Perbedaan kecemasan Reponden Sebelum Dan Setelah Perlakuan Pada Kelompok Intervensi

\begin{tabular}{ccccccc}
\hline \multirow{2}{*}{ Kelompok } & \multicolumn{2}{c}{ Sebelum Perlakuan } & \multicolumn{2}{c}{ Setelah Perlakuan } & \multirow{2}{*}{ p } \\
\cline { 2 - 6 } Intervensi & Kecemasan & $\mathbf{n}$ & $\mathbf{\%}$ & $\mathbf{n}$ & $\mathbf{\%}$ & 0,047 \\
& Tidak Cemas & 15 & 75,0 & 20 & 100,0 & \\
& Cemas & 5 & 25,0 & 0 & 0,0 & \\
\hline *Bermakna pada $\alpha<0,05$ & Total & 20 & 100,0 & 20 & 100,0 & \\
\hline
\end{tabular}

Tabel 4 Perbedaan Kecemasan Reponden Setelah Perlakuan pada Kelompok Intervensi

\begin{tabular}{|c|c|c|c|c|c|c|c|}
\hline \multirow{3}{*}{ Kelompok } & \multicolumn{6}{|c|}{ Kecemasan (Setelah perlakuan) } & \multirow{3}{*}{$\mathbf{p}$} \\
\hline & \multicolumn{2}{|c|}{ Cemas } & \multicolumn{2}{|c|}{ Tidak cemas } & \multicolumn{2}{|c|}{ Total } & \\
\hline & $\mathbf{n}$ & $\%$ & $\mathbf{n}$ & $\%$ & $\mathbf{n}$ & $\%$ & \\
\hline Kontrol & 8 & 40,00 & 12 & 60,00 & 20 & 100,0 & 0,003 \\
\hline Intervensi & 0 & 0,0 & 20 & 100,0 & 20 & 100,0 & \\
\hline
\end{tabular}

*Bermakna pada $\alpha \leq 0,05$

Tabel 5. Perbedaan Kecemasan Ibu Hamil Risiko Tinggi Sebelum dan Setelah Perlakuan pada Kelompok Intervensi dan Kelompok Kontrol Berdasarkan Gravida

\begin{tabular}{|c|c|c|c|c|c|c|c|}
\hline \multirow[b]{2}{*}{ Perlakuan } & \multirow[b]{2}{*}{ Gravida } & \multicolumn{2}{|c|}{$\begin{array}{l}\text { Tidak cemas } \\
\end{array}$} & \multirow[b]{2}{*}{$\mathbf{P}$} & \multicolumn{2}{|c|}{ Kecemasan } & \multirow[b]{2}{*}{$\mathbf{p}$} \\
\hline & & $\begin{array}{c}\text { Intervensi } \\
\%\end{array}$ & $\begin{array}{c}\text { Kontrol } \\
\%\end{array}$ & & $\begin{array}{c}\text { Intervensi } \\
\%\end{array}$ & $\begin{array}{c}\text { Kontrol } \\
\%\end{array}$ & \\
\hline $\begin{array}{l}\text { Sebelum } \\
\text { perlakuan }\end{array}$ & $\begin{array}{l}\text { Primi } \\
\text { Multi } \\
\text { Total }\end{array}$ & $\begin{array}{l}20,0 \\
55,0 \\
75,0\end{array}$ & $\begin{array}{l}55,0 \\
15,0 \\
70,0\end{array}$ & $\begin{array}{l}0,118 \\
0,057\end{array}$ & $\begin{array}{c}0,0 \\
25,0 \\
25,0\end{array}$ & $\begin{array}{l}20,0 \\
10,0 \\
30,0\end{array}$ & $\begin{array}{l}0,125 \\
0,453\end{array}$ \\
\hline $\begin{array}{l}\text { Sesudah } \\
\text { perlakuan }\end{array}$ & $\begin{array}{l}\text { Primi } \\
\text { Multi } \\
\text { Total } \\
\end{array}$ & $\begin{array}{c}20 \\
80 \\
100 \\
\end{array}$ & $\begin{array}{l}50 \\
10 \\
60 \\
\end{array}$ & $\begin{array}{l}0,180 \\
0,001\end{array}$ & $\begin{array}{l}0 \\
0 \\
0 \\
\end{array}$ & $\begin{array}{l}25 \\
15 \\
40 \\
\end{array}$ & $\begin{array}{l}0,063 \\
0,250\end{array}$ \\
\hline
\end{tabular}

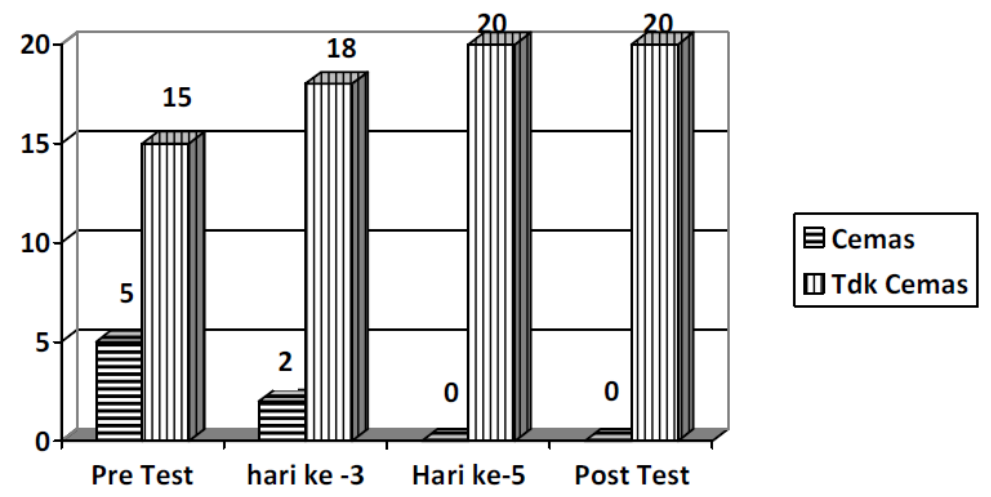

Gambar 1. Diagram Perubahan Kecemasan Ibu Hamil Kelompok Risiko Tinggi pada Kelompok Intervensi Pretest, Hari Ketiga, Hari Kelima, Post Test 


\section{Pembahasan}

Kecemasan pada kelompok intervensi dan kelompok kontrol setelah pemberian paket "Harmoni". Hasil penelitian ini menunjukkan bahwa ibu pada kelompok intervensi mengalami kecemasan, namun kemudian tidak lagi setelah mendapatkan perlakuan. Hal ini disebabkan karena kemampuan beradaptasi ibu terhadap kondisi kehamilannya meningkat. Perubahan dapat terjadi karena pemberian informasi yang komprehensif dan tepat melalui paket "Harmoni" yang membuat ibu dan pasangannya mampu mengatasi kekuatiran mereka. Penggunaan media pembelajaran dengan metode pembelajaran yang efektif dapat memfasilitasi ibu dalam menyerap informasi baru dan menerapkannya dalam kehidupan sehari-hari terutama menjelang persalinan, sehingga ibu menjadi lebih rileks dan mampu berpikir positif tentang kehamilannya.

Hal ini sesuai dengan St. John dan Emmanuel (2010), yang menyatakan bahwa kemampuan ibu beradaptasi untuk mengurangi kecemasan, sangat dipengaruhi oleh peran tenaga kesehatan dalam membantu ibu beradaptasi melalui pertimbangan personal, menjalin hubungan, dan pelayanan dalam konteks sosial. Kemampuan adaptasi dari ibu hamil risiko tinggi sangat dipengaruhi oleh tingkat stres, mekanisme koping dan karakteristik dari pasangan ibu hamil risiko tinggi (Juyong \& Euysoon, 2010). Hasil penelitian oleh Sittner, et al. (2007) dan Stankaitis, et al. (2005) juga menemukan bahwa perawatan yang komprehensif merupakan salah satu bentuk dukungan yang diberikan oleh tenaga kesehatan kepada ibu hamil dengan risiko tinggi melalui pendidikan kesehatan sehingga ibu kembali memiliki semangat dan berpikir positif tentang kehamilan dan persalinannya.

Pada kelompok kontrol didapatkan hasil posttest yang menunjukkan bahwa ada peningkatan kecemasan yang mungkin disebabkan adanya interval waktu 7 hari antara pengambilan data sebelum dan sesudah perlakuan. Adanya rentang waktu tersebut, memungkinkan ibu mendapat stresor lain yang menimbulkan kecemasan pada diri, dan tidak ada intervensi peneliti. Hal ini sesuai dengan Glynn, Schetter, Hobel, dan Sandman (2008) bahwa dua skor yang berbeda dapat diperoleh selama periode kehamilan oleh peneliti pada pengkajian awal dan diantara kunjungan peneliti berikutnya akibat sejumlah kejadian dalam kehidupan mereka. Brisch, et al. (2003) menemukan pola strategi koping ibu hamil dibedakan dalam tiga kategori yaitu: koping berorientasi kognitif, emosi dan perilaku, dan koping dalam kehamilan sangat dipengaruhi oleh informasi dan konseling dari tenaga kesehatan. Tidak semua orang mampu menggunakan mekanisme koping yang adaptif. Faktor psikososial yang mengakibatkan ketidakmampuan menggunakan mekanisme koping tersebut adalah: faktor sosial, psikologi, dan perilaku kesehatan yang tidak diinginkan (Welch \& Miller, 2008).

\section{Perbedaan kecemasan ibu hamil kelompok risiko tinggi berdasarkan gravid. Hasil} penelitian menunjukkan bahwa ibu hamil risiko tinggi multigravida yang tidak cemas berbeda bermakna pada kelompok intervensi dan kelompok kontrol setelah mendapat paket "Harmoni", sedangkan ibu primigravida dan multigravida berisiko tinggi yang cemas tidak berbeda bermakna.

Penelitian yang dilakukan Dole, et al. (2002); Stankaitis, et al. (2005); Sittner, et al. (2007); Nakamura, et al. (2011) menemukan bahwa pendidikan kesehatan diperlukan ibu untuk memperoleh kembali semangat dalam berpikir bahwa kehamilan ibu berlangsung dengan baik, dengan demikian kecemasan ibu beserta pasangan dapat diminimalkan dan komplikasi kehamilan pada persalinan dapat dicegah. Kemampuan koping seseorang dipengaruhi oleh pemberian informasi oleh tenaga kesehatan tentang tujuan dari tindakan medis yang dilakukan, termasuk dampak positif maupun negatif yang akan diperoleh ibu (Brisch, et al., 2005).

Hasil penelitian ini menunjukkan pemberian pendidikan kesehatan melalui pemberian paket "Harmoni" pada ibu hamil risiko tinggi dapat menurunkan kecemasan pada ibu hamil risiko tinggi dalam menghadapi persalinan. Paket 
"Harmoni" didasari oleh pemikiran mengenai peran perawat dalam meningkatkan peran serta keluarga dan rasa percaya diri ibu hamil risiko tinggi dalam pemenuhan kebutuhan dasar psikologis terutama bebas dari rasa cemas dalam menghadapi persalinan. Implikasi terhadap pelayanan kesehatan adalah perawat diharapkan dapat meningkatkan kemampuan ibu hamil risiko tinggi menghadapi stresor kehidupan melalui teknik relaksasi sehingga ibu dapat selalu bersikap rileks dan berpikir positif serta memiliki kepercayaan diri yang tinggi melalui peran serta seluruh keluarga dalam memberikan dukungan kepada ibu. Ibu hamil risiko tinggi dan janinnya dengan demikian dapat memperoleh kesejahteraan. Oleh karena itu, paket "Harmoni" dapat dijadikan acuan dalam memberikan pendidikan kesehatan psikososial bagi para ibu hamil risiko tinggi, sehingga kita berharap pelayanan kesehatan kepada masyarakat dapat kita tingkatkan secara optimal baik di dalam maupun di luar rumah sakit.

Keterbatasan penelitian adalah besar sampel yang kecil dan pemilihannya tidak acak sehingga pemberian paket "Harmoni" ini perlu diuji lebih lanjut dengan menggunakan metode uji klinis. Instrumen yang digunakan juga lebih baik yang langsung mengukur kecemasan atau ketakutan menghadapi persalinan.

\section{Kesimpulan}

Hasil penelitian ini menunjukkan bahwa tidak terdapat perbedaan kecemasan pada ibu hamil risiko tinggi baik pada kelompok intervensi dan kelompok kontrol sebelum diberikan perlakuan pada kelompok intervensi. Akan tetapi terdapat perbedaan kecemasan pada kelompok intervensi dan kontrol setelah pemberian paket "Harmoni" pada kelompok intervensi, dan terdapat perbedaan kecemasan ibu hamil risiko tinggi dalam menghadapi persalinan, sebelum dan sesudah pemberian paket "Harmoni" pada kelompok intervensi. Selain itu, tidak ada pengaruh gravida terhadap kecemasan ibu dalam menghadapi persalinan. Hasil penelitian ini membuktikan bahwa pemberian paket "Harmoni" pada ibu hamil risiko tinggi mem- berikan pengaruh pada tingkat kecemasan ibu menghadapi persalinan.

Paket "Harmoni" ini dapat digunakan sebagai media dalam program pendidikan kesehatan tentang pemenuhan kebutuhan psikososial pada ibu hamil risiko tinggi. Pendidikan kesehatan dengan menggunakan metode yang tepat dan efektif melalui penerapan evaluasi berulang dan bertahap pada ibu hamil risiko tinggi mampu menurunkan kecemasan ibu hamil risiko tinggi dalam menghadapi persalinan. Selain itu bagi institusi pendidikan dalam membuat program pengajaran keperawatan maternitas diharapkan menekankan kembali aspek psikososial dalam asuhan keperawatan kepada ibu hamil risiko tinggi. Asuhan keperawatan dapat dikemas dalam pendidikan kesehatan untuk pelayanan baik di rumah sakit, maupun di luar rumah sakit. Program ini dapat dilakukan melalui bentuk kerjasama antara institusi pendidikan dengan rumah sakit tempat mahasiswa praktek dalam program kunjungan rumah atau kelas antenatal (AR, SW, INR).

\section{Ucapan Terima Kasih}

Pimpinan Akademi Keperawatan Panti Waluya yang telah memberikan dana untuk mendukung pelaksanaan riset ini pada tahun 2011-2012.

\section{Referensi}

Bennington, L.K. (2012). High risk pregnancy. Life and Health Library. Encyclopedia of nursing and allied health. Diperoleh dari. http: //www.findarticles.com/

Brisch, K.H., Munz, D., KÄChele, H., Terinde, R., \& Kreienberg, R. (2005). Effects of previous pregnancy loss on level of maternal anxiety after prenatal ultrasound screening for fetal malformation. Journal of Loss and Trauma, 10 (2), 131-153. doi: 10.1080/15325020590908849.

Dole, N., Savitz, D.A., Hertz-Picciotto, I., SiegaRiz, A.M., McMahon, M.J., \& Buekens, P. (2003). Maternal stress and preterm birth. Am. J. Epidemiol, 157 (1), 14-24. doi:10.1093/aje/k wf176. 
Foux, R. (2008). Sex education in pregnancy: Does it exist? A literature review. Sexual and relationship therapy, 23, (3), 271-277.

Gilbert, E.S \& Harmon, J.S. (2010). Manual of high risk pregnancy \& delivery. (5th Ed). St. Louis: Mosby.

Glynn, L.M., Schetter, C.D., Hobel, C.J., Sandman, C.A. (2008). Pattern of perceived stress and anxiety in pregnancy predicts preterm birth. Health Psychology, 27(1), 43-51.

Juyoung, L., \& Euysoon, C. (2010). Stress and coping style of high risk pregnant women's spouses. Korean Journal Women's Health Nursing, 16 (3), 234-244.

Raja Lexshimi, R.G., Ho, S.E, Hamidah, H., Rohani, M., \& Syed Zulkifli, S.Z. (2007). A study on anxiety and depression level among high risk in patient pregnant women in an obstetric ward. Med \& health, 2 (1), 34-41.

Nakamura, Y., Yoshizawa, T., \& Atogami, F. (2011). Assesments of maternal psycho- social adaptation for pre-labor hospitalized pregnant women in Japan. Nusrep, 1:e9, 35-39. doi:10. 4081/nursrep. 2011.e9 .
Stankaitis, J.A, Brill, H.R and Walker, D.M. (2005).Reduction in neonatal intensive care unit admission rates in a medical managed care program.American $J$ of Managed Care, 11, 166-172.

Sittner, B.J, Hudson, D.B, \& Defrain J. (2007). Using the concept of Family strengths to enhance nursing care. $M C N, 32(6), 353-357$.

St John, W., \& Emmanuel, E. (2010). Maternal distress: A concept analysis. Journal of Advanced Nursing, 66(9), 2104-2115.

Welch, L.G., \& Miller, L.A. (2008). Emotional and educational components of pregnancy. Library Women's med. (ISSN: 1756-2228). doi: 10.38 43GLOWM.10415.

WHO. (2013). Health promotion. Diunduh dari http://www.who.int/topics/health_promotion/ en/. 